\title{
Medicinal plants of southeast ohio, USA
}

\begin{abstract}
Southeast Ohio is the most geologically and biologically rich corner of the state. The area contains thousands of acres of forests, valleys and open fields, making it home to countless plant and animal species. The plants were collected from four areas including Blackhand trail, Dillon Falls, Frazeysburg, and Warsaw. The studied area has had no previous botanical collecting of medicinal plants. Making it an urgent need to be inventoried and analyzed in order to identify the endemic, rare, and endangered species to protect them. This survey documented 43 species in 31 families. The families with the most species were Asteraceae (5), and Rosaceae (4). No State-listed threatened or endangered species were found. The studied area has a diverse flora of medicinal plants.
\end{abstract}

Keywords: Southeast, Flora, Medicinal Plants, Inventory, Ohio
Volume 8 Issue 2 - 2018

\author{
Mohannad G Al-Saghir \\ Department of Environmental and Plant Biology, Ohio \\ University, USA
}

\begin{abstract}
Correspondence: Mohannad G Al-Saghir, Department of Environmental and Plant Biology, Ohio University, Zanesville, Ohio, USA, Email: al-saghi@ohio.edu
\end{abstract}

Received: February II, 2018| Published: March 05, 2018

\section{Introduction}

Southeast Ohio is the most geologically and biologically rich corner of the state. The area contains thousands of acres of forests, valleys and open fields, making it home to countless plant and animal species. ${ }^{1}$ In addition to the towering hardwoods, the many parks are alive with wildflowers, ferns and the state wildflower white trillium. One of the most visually compelling geological features in Southeast Ohio, the author noted, is the Black Hand sandstone, a substance found nowhere else in the state. A vestige from the days when the area was covered by an inland sea, this rock forms the basis of soaring cliffs, recessed valleys, and slender tunnels. Studded with rusting iron oxide, the sandstone twinkles with beautiful colors. ${ }^{1,2}$ Before conventional medicine became available, most people relied on indigenous plants to heal their wounds and ailments. These days, an increasing number of people are shying away from over-the-counter remedies when possible and shifting back to medicinal plants as a way to regain their health. Therefore, collecting and studying these valuable plants is a necessity especially from area like Southeast Ohio. The studied area has had no previous botanical collecting. Therefore, the area was in urgent need to be inventoried and analyzed in order to identify and document its medicinal plants. Moreover, these identified species will be used for educational purposes for both the students and the public. Most people (due to the lack of knowledge) remove or kill these plants because they thought they were weeds. Moreover, lots of people don't even know these plants exist in Ohio. This inventory makes this area a model for the other areas and parks in the state to identify the floral composition of these parks. This project represents the first inventory of the medicinal Plants of the area. The objectives of this study were to: 1) conduct inventory of the Medicinal Plants of the area in order to identify the endemic, rare, and endangered species to protect them;2) document the medicinal Plants of the area; and 3) prepare a voucher collection of each species known to occur in the area.

\section{Collection Site}

The plants were collected from the following areas: Blackhand trail, Dillon Falls, Frazeysburg, and Warsaw.

\section{Materials and methods}

Plant specimens were collected from the studied areas in June and July 2010. The study was done in the herbarium of Ohio UniversityZanesville. Plants were identified using Braun (1961 and 1967), ${ }^{1,2}$ Cooper rider 1995, ${ }^{3}$ Fisher 1988, ${ }^{4}$ Flora of North America Editorial Committee FNA; 1993, ${ }^{5}$ Gleason and Cronquist (1991), ${ }^{6}$ and Holmgren (1998) ${ }^{7}$. Species nomenclature follow Cooperrider et al. ${ }^{3}$ Family classification of seed plants follows Judd et al. ${ }^{8}$

\section{Results}

This survey documented 43 species in 31 families (Appendix A). The families with the most species were Asteraceae (5), and Rosaceae (4). No State-listed threatened or endangered species were found.

\section{Discussion}

The following paragraphs detail the key characteristics and the vegetation for each area based on this inventory.

\section{Backhand Trail}

The Black Hand trail is a state nature preserve. It characterized by steep slopes, dense shade, and well-drained soils with a thin layer organic soil layer. Vegetation: Daucus carota, Galium aparine, Panax quinquefolius, and Typha latifolia.

\section{Dillon falls}

The area is a dynamic environment. Conditions appear to fluctuate rapidly with weather events. Vegetation suitable for the zone should be capable of withstanding fluctuating water levels. The area is characterized by well-drained soils, greater exposure to sun and wind, fewer over story trees, and drier conditions.

Vegetation: Aesculus hippocastanum, Arctium minus, Asclepias purpurascens, Asclepias syriaca, Conium maculatum, Dioscorea villosa, Erigeron philadelphicus, Fragaria virginiana, Julgans nigra, Impatiens capensis, Heracleum maximum, Menispermum canadense, Parthenocissus quinquefolia, Phytolacca americana, Rosa multifora, 
Rubus allegheniensis, Rumex crispus, Sambucus canadensis, Ulmus rubra, Urtica dioica, Verbesina alternifolia, Viola papilionacea, and Vitis riparia.

\section{Frazeysburg}

It characterized by thin strips of residual vegetation. Ratio of edge to interior is high. Often associated with fencerows, division between agricultural fields, etc. Characterized by scrub growth, early succession species, and large over story trees. Vegetation: Asparagus officinalis, Mentha spicata, Taraxacum officinale.

\section{Warsaw}

The area depicted as meadow are similar in that they are composed primarily of forbs and grasses. The underlying topography is different, however, which heavily influences the vegetation. The meadow sits on well-drained soil, with full sun. Vegetation: Acorus calamus, Cichorium intybus, Hydrastis canadensis, Nasturtium officinale, Rhus glabra, Rosa acicularis, Sassfras albidum, Stellaria media, Symplocarpus foetidus, Thymus vulgaris, Trifolium campestre, and Trifolium pretense, (Figure 1).

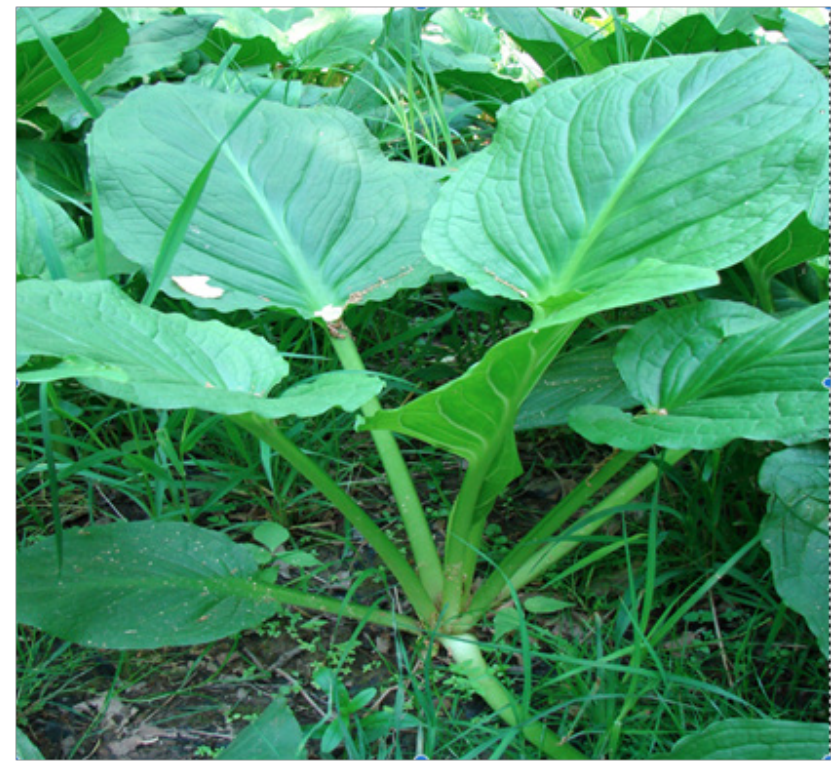

Figure I Symplocarpus foetidus

\section{Conclusion}

Plant specimens were collected from four sites during two field seasons (spring and summer) of 2010. Each specimen was reviewed by specialists for correct determinations, data entered into site, collection, and taxonomic databases, specimens were labeled, mounted, and filed in the Ohio University-Zanesville herbarium. The studied area has a diverse flora of medicinal plants. These specimens will be kept in the herbarium database which was established specifically for this project, including the locations and herbaria of deposition of all specimens collected in the studied area. This project will have a collaborative network encompassing many partners (Mission Oaks, The Dawes Arboretum, The Wilds, and the Muskingum Valley Park District) as this inventory was the first one to be done to this area.

\section{Acknowledgment}

The author is thankful for the Ohio University Zanesville for funding this project.

\section{Conflict of interest}

None.

\section{Appendix A}

The list is arranged alphabetically within major divisions. Species nomenclature follows Cooperrider et al. (2001). Family classification of seed plants follows Judd et al. (2002). (B) Stands for Blackhand trail, (D) stands for Dillon Falls, (F) for Frazeysburg, (W) for Warsaw.

\begin{tabular}{l} 
Acoraceae \\
\hline Acorus calamus L., W
\end{tabular}

Adoxaceae

Sambucus canadensis L., D

Anacardiaceae

Rhus glabra L., W

Apiaceae

Conium maculatum L., D

Daucus carota L., B

Heracleum maximum Bartram, D

Apocynaceae

Asclepias purpurascens L., D

Asclepias syriaca L., D

Araceae

Symplocarpus foetidus (L.) Nutt., W

Araliaceae

Panax quinquefolius L., B

Asparagaceae

Asparagus officinalis L., $\mathbf{F}$

Asteraceae

Arctium minus (Hill) Bernh., D

Cichorium intybus L., W

Erigeron philadelphicus L., D

Taraxacum officinale F.H. Wigg., F

Verbesina alternifolia (L.) Britton, D

Balsalminaceae

Impatiens capensis Meerb., D

Brassicaceae

Nasturtium officinale W.T. Aiton, W

Caryophyllaceae

Stellaria media (L.) Vill.,, W

Dioscoreacea

Dioscorea villosa L., D

Fabaceae

Trifolium campestre Schreb., W 
Trifolium pretense L., W

Hippocastanaceae

Aesculus glabra Willd., E

Juglandaceae

Julgans nigra L., D

Lamiaceae

Mentha spicata L., F

Thymus vulgaris L., W

\section{Lauraceae}

Sassfras albidum (Nutt.) Nees, W

\section{Menispermaceae}

Menispermum canadense L., D

Phytolaccaceae

Phytolacca americana L., D

\section{Polygonaceae}

Rumex crispus L. D

\section{Ranunculaceae}

Hydrastis canadensis L., W

\section{Rosaceae}

Fragaria virginiana Duchesne, D

Rosa acicularis Lindl., W

Rosa multifora Thunb., D

Rubus allegheniensis Porter, D

\section{Rubiaceae}

Galium aparine L., B

\section{Sapindaceae}

Aesculus hippocastanum L., D

\section{Typhaceae}

Typha latifolia L., B

\section{Ulmaceae}

Ulmus rubra Muhl., D

\section{Urticaceae}

Urtica dioica L., D

\section{Violaceae}

Viola papilionacea Pursh, D

Vitaceae

Parthenocissus quinquefolia (L.) Planch., D

Vitis riparia Michx., D

\section{References}

1. Braun EL. The Woody Plants of Ohio. Ohio State University Press, Columbus; 1961; OH

2. Braun EL. The Monocotyledoneae: Cattails to Orchids. Ohio State University Press, Columbus, 1967; OH.

3. Coopeerider TS, AW Cusick, JT Kartesz, editors. Seventh Catalog of the Vascular Plants of Ohio; Ohio State University Press, Columbus, 2001; OH.

4. Fisher TR. The Dicotyledoneae of Ohio, Part 3: Asteraceae. Ohio State University Press, Columbus, 1988; OH.

5. Flora of North America Editorial Committee, editors. Flora of North America North of Mexico, Vol. 2. Pteridophytes and Gymnosperms. 1993; 2: Oxford Univ. Press, Oxford and New York.

6. Gleason HA, A Cronquist. Manual of Vascular Plants of Northeastern United States and Adjacent Canada, $2^{\text {nd }}$ ed. The New York Botanical Garden, Bronx; 1991; NY.

7. Holmgren NH. Illustrated Companion to Gleason and Cronquist's Manual. 1998; The New York Botanical Garden, Bronx, NY.

8. Judd WS, CS Campbell, EA Kellogg, et al. Plant Systematic: A Phylogenetic Approach, $2^{\text {nd }}$ ed. Sinauer Associates, Inc., Sunderland, Plan sciences. 1999; pp. 208. 